\title{
Video Article \\ Affinity Purification of Chloroplast Translocon Protein Complexes Using the TAP Tag
}

\author{
Venkatasalam Shanmugabalaji ${ }^{1}$, Véronique Douet ${ }^{1}$, Birgit Agne $^{2}$, Felix Kessler ${ }^{1}$ \\ ${ }^{1}$ Laboratory of Plant Physiology, University of Neuchatel \\ ${ }^{2}$ Institut fur Biochemie und Biotechnologie, Martin-Luther-Universitat Halle-Wittenberg
}

Correspondence to: Felix Kessler at felix.kessler@unine.ch

URL: https://www.jove.com/video/58532

DOI: doi: $10.3791 / 58532$

Keywords: Biochemistry, Issue 141, Chloroplast, TOC-TIC Complex, TAP tag, TOC159, IgG binding, TEV protease, affinity purification.

Date Published: 11/1/2018

Citation: Shanmugabalaji, V., Douet, V., Agne, B., Kessler, F. Affinity Purification of Chloroplast Translocon Protein Complexes Using the TAP Tag. J. Vis. Exp. (141), e58532, doi:10.3791/58532 (2018).

\section{Abstract}

Chloroplast biogenesis requires the import of thousands of nucleus-encoded proteins into the plastid. The import of these proteins depends on the translocon at the outer (TOC) and inner (TIC) chloroplast membranes. The TOC and TIC complexes are multimeric and probably contain yet unknown components. One of the main goals in the field is to establish the complete inventory of TOC and TIC components. For the isolation of TOC-TIC complexes and the identification of new components, the preprotein receptor TOC159 has been modified N-terminally by the addition of the tandem affinity purification (TAP) tag resulting in TAP-TOC159. The TAP-tag is designed for two sequential affinity purification steps (hence "tandem affinity"). The TAP-tag used in these studies consists of a N-terminal IgG-binding domain derived from Staphylococcus aureus Protein A (ProtA) followed by a calmodulin-binding peptide (CBP). Between these two affinity tags, a tobacco etch virus (TEV) protease cleavage site has been included. Therefore, TEV protease can be used for gentle elution of TOC159-containing complexes after binding to IgG beads. In the protocol presented here, the second Calmodulin-affinity purification step was omitted. The purification protocol starts with the preparation and solubilization of total cellular membranes. After the detergent-treatment, the solubilized membrane proteins are incubated with IgG beads for the immunoisolation of TAP-TOC159-containing complexes. Upon binding and extensive washing, TAP-TOC159 containing complexes are cleaved and released from the IgG beads using the TEV protease whereby the $S$. aureus IgG-binding domain is removed. Western blotting of the isolated TOC159-containing complexes can be used to confirm the presence of known or suspected TOC and TIC proteins. More importantly, the TOC159-containing complexes have been used successfully to identify new components of the TOC and TIC complexes by mass spectrometry. The protocol that we present potentially allows the efficient isolation of any membrane-bound protein complex to be used for the identification of yet unknown components by mass spectrometry.

\section{Video Link}

The video component of this article can be found at https://www.jove.com/video/58532/

\section{Introduction}

Plants depend on chloroplasts for photosynthesis and photoautotrophic growth ${ }^{1}$. The vast majority of chloroplast proteins are encoded in the nucleus, synthesized in the cytosol and imported into the chloroplast via the TIC and TOC complexes in the envelope membranes ${ }^{2}$. The core of the TOC complex consists of the Toc75 protein-conducting channel and the two receptor GTPases Toc33 and Toc159 $3,4,5$. TOC159 is essential for the biogenesis of chloroplasts and mediates the massive accumulation of photosynthesis-associated proteins ${ }^{6}$. The TIC complex consists of the TIC20 protein-conducting channel as well as TIC110 and TIC40 7,8 . Recently, a $1 \mathrm{MD}$ protein translocation complex at the inner envelope membrane was isolated and contained previously unidentified components ${ }^{9}$, one of which was TIC56. We recently co-isolated TIC56 of the 1 MDa complex using the TAP-TOC159 affinity purification protocol. The data indicated a structural overlap between the "canonical" TOC/TIC complexes and the $1 \mathrm{MDa}$ complex ${ }^{10}$. Previously unknown components such as KOC1 were also identified as new interaction partners of the TOC and TIC complexes using the TAP-method described here ${ }^{10,11}$

Thus, the TAP-tag purification is an efficient method for the isolation of protein complexes and the identification of interacting partners by subsequent mass spectrometric analysis ${ }^{12}$. The TAP tag consists of two $\mathrm{lgG}$ binding repeats separated from a calmodulin-binding peptide (CBP) by a tobacco etch virus (TEV) protease cleavage site. The original method, consisting of an IgG-affinity purification step followed by TEV cleavage and subsequent calmodulin-affinity chromatography permitted the native purification of large and highly pure protein complexes ${ }^{13,14}$. We have simplified the procedure and demonstrated that the TOC159-containing protein complexes can also be purified efficiently using only the IgG-affinity purification step followed by TEV-cleavage for elution ${ }^{15}$. In our experience, the omission of the calmodulin-affinity step resulted in higher yields and may therefore be appropriate for low abundance proteins.

In short, we engineered stable transgenic $A$. thaliana lines expressing TAP-TOC159 in the ppi2 (toc159 KO mutant) background and established it as a reliable source for the purification of TOC-TIC complexes. The protocol for the isolation of the TOC-TIC complex starts with the homogenization of the plant material in a detergent-free buffer. After centrifugation, the supernatant is discarded. The pellet containing the total membrane fraction is solubilized using a detergent-containing buffer. After an ultra-centrifugation step, the supernatant containing solubilized 
TOC-TIC complexes is applied to the IgG-resin for affinity purification. After several washing steps, elution is carried out using a TEV proteasecontaining buffer to selectively cleave downstream of the lgG-binding domains and gently release native TOC159-containing complexes. The TEV eluate can be analyzed directly by Western blotting or mass spectrometry to identify the interaction partners of TOC $159^{10,11,15}$. The method has also been used to identify post-translational modifications of TOC $159^{15}$. In the future, native TOC159-containing complexes may be used for structural studies using cryoelectron microscopy.

\section{Preparation of Arabidopsis Plants}

1. Prepare $1 \mathrm{~L}$ of half strength of Murashige and Skoog (MS) medium including vitamins with $1 \%$ sucrose and adjust the $\mathrm{pH}$ to 5.7 with potassium hydroxide $(\mathrm{KOH})$. Add $0.8 \%$ of phytoagar and autoclave for $20 \mathrm{~min}$ at $120^{\circ} \mathrm{C}$.

2. Pour $75 \mathrm{~mL}$ of MS medium per Petri plate (diameter $14.5 \mathrm{~cm}$, height $3 \mathrm{~cm}$ ) and allow the solidification for $1 \mathrm{~h}$.

3. Add $30 \mathrm{mg}$ of Arabidopsis thaliana seeds to a $1.5 \mathrm{~mL}$ microfuge tube, and surface sterilize with $70 \%(\mathrm{v} / \mathrm{v}$ ) ethanol containing $0.05 \%$ ( $/ \mathrm{v}$ ) Triton X-100 for $5 \mathrm{~min}$, followed by $100 \%$ (v/v) ethanol for $10 \mathrm{~min}$. Remove the ethanol.

4. Transfer the seeds to sterile filter paper for drying. Sprinkle the sterilized seeds evenly onto a MS plate (each genotype requires at least 8-10 plates), and seal each plate with surgical tape.

5. Incubate the plates at $4{ }^{\circ} \mathrm{C}$ for two days in the dark to synchronize seed germination. Transfer to a growth chamber with the following light cycle: $8 \mathrm{~h}$ of $120 \mu \mathrm{mol} \mathrm{m} \mathrm{s}^{-1}$ light, and $16 \mathrm{~h}$ of dark at $22-20^{\circ} \mathrm{C}$.

\section{Preparation of HslgG Agarose Beads}

1. Suspend $\mathrm{CNBr}$-activated agarose beads $(4 \mathrm{~g})$ in $100 \mathrm{~mL}$ of $1 \mathrm{mM} \mathrm{HCl}$ and incubate for 30 min at room temperature.

2. Transfer the agarose beads into a sintered glass filter, wash under vacuum with $100 \mathrm{~mL}$ of $100 \mathrm{mM} \mathrm{HCl}$ and repeat 2-3 times. NOTE: Precool the wash solution to $4{ }^{\circ} \mathrm{C}$.

3. Resuspend the agarose beads in $1 \mathrm{~mL}$ of cold $100 \mathrm{mM} \mathrm{HCl}$ and transfer to a $50 \mathrm{~mL}$ conical centrifuge tube. Wash the sintered glass filter with $3 \mathrm{~mL}$ of $100 \mathrm{mM} \mathrm{HCl}$ and transfer the liquid to the same tube.

4. Spin at $400 \times g$ for $5 \mathrm{~min}$ at $4{ }^{\circ} \mathrm{C}$ and remove the supernatant with a pipette. NOTE: Do not decant the tube.

5. Resuspend the beads in $50 \mathrm{~mL}$ of coupling buffer (Table 1); mix briefly, and then spin at $400 \times g$ for 5 min at $4{ }^{\circ} \mathrm{C}$

6. Dissolve $50 \mathrm{mg}$ of lyophilized Homo sapiens IgG (Hs-lgG) in $10 \mathrm{~mL}$ of coupling buffer, mix the agarose beads gently, and incubate in rotary shaker overnight at $4{ }^{\circ} \mathrm{C}$.

7. Spin at $400 \times g$ for $5 \mathrm{~min}$ at $4{ }^{\circ} \mathrm{C}$ and remove the supernatant with a pipette.

8. Wash the IgG-agarose beads with $50 \mathrm{~mL}$ of coupling buffer and spin at $400 \times \mathrm{g}$ for $5 \mathrm{~min}$ at $4^{\circ} \mathrm{C}$.

9. Resuspend the IgG-agarose beads with $50 \mathrm{~mL}$ of blocking buffer (Table 1) and spin at $400 \times g$ for 5 min at $4{ }^{\circ} \mathrm{C}$. Repeat once.

10. Resuspend IgG-agarose beads in $50 \mathrm{~mL}$ of blocking buffer, rotate the mixture for $2 \mathrm{~h}$ at RT and spin at $400 \times g$ for $5 \mathrm{~min}$ at $4{ }^{\circ} \mathrm{C}$.

11. Remove the supernatant and resuspend the IgG-agarose beads in $200 \mathrm{~mL}$ of $\mathrm{NaCl}$ coupling buffer (Table 1).

12. To block any remaining cross-linking $\mathrm{CNBr}$ groups, wash the lgG-agarose beads with $100 \mathrm{~mL}$ of $0.1 \mathrm{M} \mathrm{glycine-HCl,} \mathrm{pH} 2.8$. Spin at 400 $\times g$ for 5 min at $4{ }^{\circ} \mathrm{C}$ and remove the supernatant. Wash with $0.2 \mathrm{M}$ glycine- $\mathrm{HCl}, \mathrm{pH} 2.8$, spin at $400 \times g$ for 5 min at $4{ }^{\circ} \mathrm{C}$ and remove the supernatant. Finally, wash the lgG-agarose beads with $200 \mathrm{~mL}$ of ultrapure water.

13. Wash the IgG-agarose beads with $200 \mathrm{~mL}$ of ultrapure water and then $200 \mathrm{~mL}$ of PBS buffer (Table 1).

14. Resuspend the IgG-agarose beads in $20 \mathrm{~mL}$ of PBS buffer with $0.01 \% \mathrm{NaN}_{3}$ (sodium azide) and store at $4{ }^{\circ} \mathrm{C}$.

\section{Isolation and Solubilization of the Membrane Fraction}

1. Grind $10 \mathrm{~g}$ of three weeks old $A$. thaliana seedlings in liquid nitrogen using a cold mortar and pestle with sand.

2. Add $20 \mathrm{~mL}$ of cold grinding buffer (Table 1) to $10 \mathrm{~g}$ of ground tissue, mix well, and thaw on ice.

3. Filter the homogenate through two layers of quick filtration material into a $50 \mathrm{~mL}$ conical centrifuge tube. Soak the quick filtration material with grinding buffer before filtration.

4. Centrifuge the filtrate for $10 \mathrm{~min}$ at $1,500 \times g$ at $4{ }^{\circ} \mathrm{C}$ and transfer the supernatant to a chilled $50 \mathrm{~mL}$ conical centrifuge tube, repeat the same step one more time and collect the supernatant. Retain a $200 \mu \mathrm{L}$ sample of the "total fraction" and store at $-80^{\circ} \mathrm{C}$ for later analysis

5. Transfer the supernatant to cold $38.50 \mathrm{~mL}$ ultracentrifuge tubes and top up to $35 \mathrm{~mL}$ with cold grinding buffer. Centrifuge for $1 \mathrm{~h}$ at $100,000 \times$ $g$ at $4{ }^{\circ} \mathrm{C}$ in an ultracentrifuge.

6. Transfer the supernatant to a $50 \mathrm{~mL}$ conical centrifuge tube. Retain a $200 \mu \mathrm{L}$ sample of the "soluble fraction" and store at $-80{ }^{\circ} \mathrm{C}$ for later analysis.

7. Re-suspend the green pellet using a glass teflon homogenizer, in grinding buffer. Centrifuge for $1 \mathrm{~h}$ at $100,000 \times g$ at $4{ }^{\circ} \mathrm{C}$ in an ultracentrifuge and discard the supernatant.

8. Resuspend the green pellet in $18.75 \mathrm{~mL}$ of $1 \mathrm{x}$ grinding Buffer using a glass teflon homogenizer and add $9.375 \mathrm{~mL}$ of $1 \mathrm{x}$ grinding buffer.

9. Add $9.375 \mathrm{~mL}$ of $4 x$ solubilisation solution (Table 1) (containing the TX-100 detergent) to give $37.5 \mathrm{~mL}$ and incubate for $30 \mathrm{~min}$ on a "rotating shaker" at $4{ }^{\circ} \mathrm{C}$.

10. Centrifuge for $1 \mathrm{~h}$ at $100,000 \times g$ at $4{ }^{\circ} \mathrm{C}$ in an ultracentrifuge. Transfer the supernatant to a $50 \mathrm{~mL}$ conical centrifuge tube. Retain a $200 \mu \mathrm{L}$ sample of the supernatant (future "load fraction") and store at $-80^{\circ} \mathrm{C}$ for later analysis.

11. Resuspend the pellet in $37.5 \mathrm{~mL}$ of grinding buffer. Retain the sample of insoluble part and store at $-80^{\circ} \mathrm{C}$ 


\section{Immunoprecipitation}

1. Equilibrate $100 \mu \mathrm{L}$ of packed IgG-agarose resin in Buffer $\mathrm{A}$ (Table 1) and spin at $100 \times g$ for 5 min at $4{ }^{\circ} \mathrm{C}$.

2. Remove the supernatant and resuspend the IgG-agarose resin in $100 \mu \mathrm{L}$ of Buffer $\mathrm{A}$ at $4{ }^{\circ} \mathrm{C}$.

3. Transfer the washed IgG-agarose resin to the $37.5 \mathrm{~mL}$ of solubilized membranes and incubate overnight on a rotating shaker in a $50 \mathrm{~mL}$ conical centrifuge tube at $4{ }^{\circ} \mathrm{C}$.

4. Sediment the $\operatorname{lgG}$-agarose resin at $100 \times \mathrm{g}$ for $5 \mathrm{~min}$ at $4^{\circ} \mathrm{C}$ and remove the supernatant with a pipette. Retain a $200 \mu \mathrm{L}$ sample of the "flow through" and store at $-80^{\circ} \mathrm{C}$ for later analysis.

5. Wash the IgG-agarose resin in $37.5 \mathrm{~mL}$ of Buffer $A$ and incubate for $10 \mathrm{~min}$ on a rotating shaker.

6. Sediment the IgG-agarose resin at $100 \times g$ for $5 \mathrm{~min}$ at $4{ }^{\circ} \mathrm{C}$, remove the supernatant with a pipette, add $5 \mathrm{~mL}$ of grinding Buffer $\mathrm{A}$ to a $15 \mathrm{~mL}$ centrifuge tube and centrifuge at $100 \times \mathrm{g}, 4^{\circ} \mathrm{C}, 5 \mathrm{~min}$. Retain a $200 \mu \mathrm{L}$ sample of the "Wash 1 " and store at $-80^{\circ} \mathrm{C}$ for later analysis.

7. Repeat the $5 \mathrm{~mL}$ washing step three times with Buffer $\mathrm{A}$.

8. Carry out the last two washing steps without the inhibitors (NaF, Protease inhibitor and PMSF) NOTE: Inhibitors are no longer required at this stage and omitted to reduce cost. Retain a $200 \mu \mathrm{L}$ sample of the last washing step "final wash (W6)" and store at $-80^{\circ} \mathrm{C}$ for later analysis.

9. Transfer the IgG-agarose resin to a $500 \mu \mathrm{L}$ spin column with a $35 \mu \mathrm{m}$ filter and wash the beads twice with $300 \mu \mathrm{L}$ of TEV elution buffer (Table 1) (not containing AcTEV) for equilibration. Close the spin column.

10. Add $300 \mu \mathrm{L}$ of TEV elution buffer containing 50 units $(10 \mu \mathrm{L})$ of AcTEV. Prepare the mix in a tube before adding to the resin.

11. Incubate the spin column with beads in a thermomixer at $16^{\circ} \mathrm{C}, 350 \mathrm{rpm}$ for $2 \mathrm{~h}$. Invert the column gently several times every 30 min.

12. Open the spin column, place it in a new clean $1.5 \mathrm{~mL}$ tube and spin at $100 \times \mathrm{g}$ for $5 \mathrm{~min}$ at $4{ }^{\circ} \mathrm{C}$ to collect the eluate.

13. Dry (for instance) $10 \%(\mathrm{v} / \mathrm{v})$ of the eluted sample $(\sim 25 \mu \mathrm{L})$ in a centrifugal evaporator and use for mass spectrometry or other further analysis.

14. Aliquot the remaining eluate $(275 \mu \mathrm{L})$ divided in to eleven $1.5 \mathrm{~mL}$ centrifuge tubes $(25 \mu \mathrm{L}$ each), dry in a centrifugal evaporator, and store at $-80^{\circ} \mathrm{C}$.

15. Analyze the samples retained throughout the procedure as well as the eluates by standard SDS-PAGE followed by immunoblotting. For sample preparation, precipitate $50 \mu \mathrm{g}$ of Total (T), Load (L), Flow through (FT), Wash 1 (W1) and $200 \mu \mathrm{L}$ of Wash 6 (W6) by chloroform/ methanol extraction ${ }^{16}$.

16. Add $10 \mu \mathrm{L}$ of $2 x$ SDS-PAGE loading buffer (Table 1) to the precipitated samples and $25 \mu \mathrm{L}$ of eluted dried sample. Vortex and boil for 10 min at $95^{\circ} \mathrm{C}$ in a heat block.

17. Analyze Total (T), Load (L), Flow through (FT), Wash 1 (W1), Wash 6 (W6) and Elution (E) by immunoblotting using anti-TOC159 antibodies to determine the efficiency of the isolation procedure.

\section{Representative Results}

We here described a protocol for the purification of a TAP-tagged chloroplast envelope protein complex from transgenic $A$. thaliana plants. As shown in Figure 1A, plants expressing the 35S:NTAP-TOC159 construct were used to isolate this complex while plants expressing the 35S:NTAP construct were used as a control. Figure 1B shows detailed steps of the purification of TAP-TOC159 protein complexes followed by mass spectrometry to allow the identification of interacting proteins. The immunoblot analysis (Figure 2, right side) confirms that isolated TAPTOC159 interacts with TOC75 and TOC33 of the TOC complex. The chloroplast outer membrane kinase KOC1 known to phosphorylate TOC159 also co-isolated with the TAP-TOC159 complex (Figure 2B, right side). The presence of TIC110 reveals that the isolated TAP-TOC159 complex also contains the components of the TIC complex. The FBN1A antibody raised against a plastoglobule protein unrelated to protein import did not recognize the TAP-TOC159 complex indicating the absence of contaminations. In the negative control, immunoprecipitated NTAP protein did not co-isolate with any of the TOC-TIC proteins (Figure 2, left side) and confirms the specificity of the TAP-TOC159 purification. 


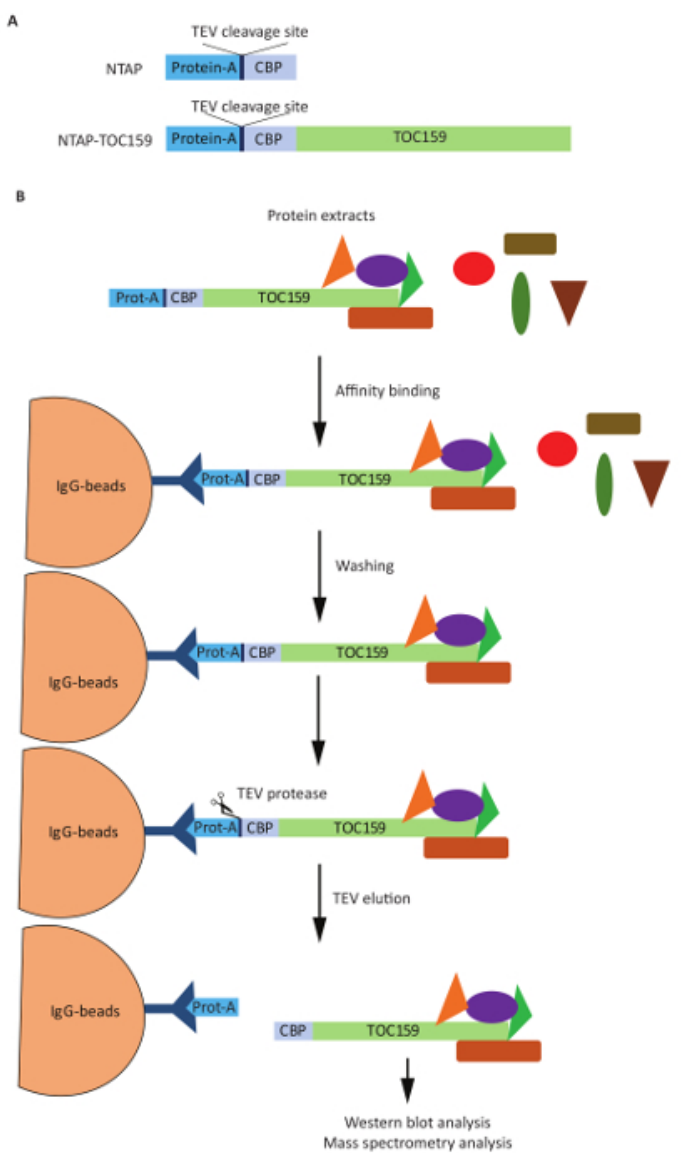

Figure 1. Scheme of the constructs and affinity purification procedure. (A). The 35S:NTAP-TOC159 construct, encoding NTAP-TOC159 was stably expressed in Arabidopsis thaliana. Negative control plants expressed the 35S:NTAP construct, encoding the TAP-tag alone. (B). The step wise affinity purification protocol consists of membrane isolation and solubilization, IgG agarose immuno-purification, washes, TEV protease cleavage and elution. Please click here to view a larger version of this figure.

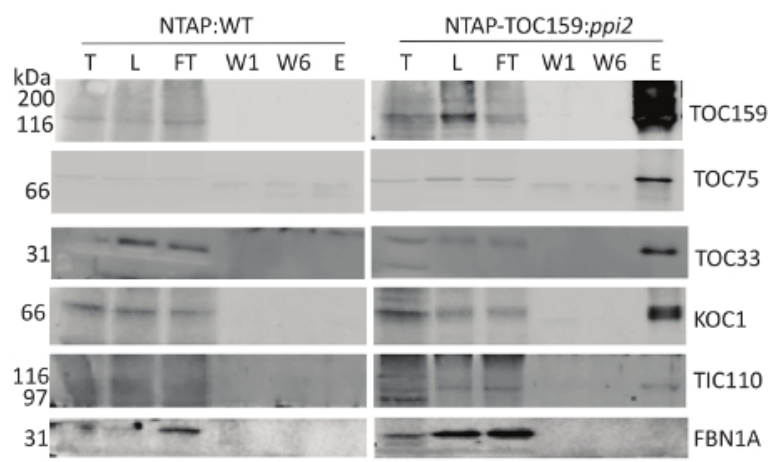

Figure 2. Tandem affinity purification of the TOC159 protein. N-terminally TAP-tagged TOC159 was purified from NTAP-TOC15:ppi2 Arabidopsis plants and TAP protein purified from TAP:WT plants was used as a negative control. Total protein extracts (T), solubilized membrane proteins = load fraction (L), flow through (FT), first and last wash fractions (W1 and W6) and 10\% of the TEV eluate were analyzed by Western blotting. The membrane was probed with the antibodies against TOC159 (AT4G02510), TOC75 (AT3G46740), TOC33 (AT1G02280), KOC1 (AT4G32250), TIC110 (AT1G06950), and FBN1A (AT4G04020). Please click here to view a larger version of this figure. 


\begin{tabular}{|c|c|c|}
\hline Table of buffers & & \\
\hline Coupling Buffer & $\begin{array}{l}\mathrm{NaHCO}_{3} \\
\text { Adjust to pH } 8.5 \text { adjust pH with } 0.1 \mathrm{M} \mathrm{Na}_{2} \mathrm{CO}_{3}\end{array}$ & $100 \mathrm{mM}$ \\
\hline Blocking Buffer & $\begin{array}{l}\text { Tris- } \mathrm{HCl} \\
\text { Adjust to } \mathrm{pH} 8 \text { with } \mathrm{HCl} \text {. }\end{array}$ & $100 \mathrm{mM}$ \\
\hline PBS Buffer & $\begin{array}{l}\mathrm{Na}_{2} \mathrm{HPO}_{4} \\
\mathrm{KH}_{2} \mathrm{PO} 4 \\
\mathrm{NaCl} \\
\mathrm{KCl} \\
\text { Adjust to } \mathrm{pH} 7.3 \text { with } \mathrm{HCl} \text {. }\end{array}$ & \begin{tabular}{|l}
$4.3 \mathrm{mM}$ \\
$1.4 \mathrm{mM}$ \\
137 \\
2.7
\end{tabular} \\
\hline $\mathrm{NaCl}$ coupling Buffer & $\begin{array}{l}\text { Coupling buffer } \\
\mathrm{NaCl}\end{array}$ & $1 \mathrm{M}$ \\
\hline $2 \mathrm{X}$ grinding Buffer & $\begin{array}{l}\text { Tris- } \mathrm{HCl}, \mathrm{pH} 7.5 \text { with } \mathrm{HCl} . \\
\mathrm{NaCl} \\
\mathrm{NaF} \\
\mathrm{PMSF} \\
\text { Plant protease inhibitor cocktail }\end{array}$ & $\begin{array}{l}100 \mathrm{mM} \\
200 \mathrm{mM} \\
5 \mathrm{mM} \\
1 \mathrm{mM} \\
0.20 \%\end{array}$ \\
\hline $4 \mathrm{X}$ solubilisation solution & $\begin{array}{l}\text { Glycerol } \\
\text { Triton-X100 }\end{array}$ & $\begin{array}{l}40 \% \\
3 \%\end{array}$ \\
\hline Buffer A & $\begin{array}{l}\text { 2X grinding Buffer } \\
1 X \text { grinding Buffer } \\
4 X \text { solubilisation solution }\end{array}$ & $\begin{array}{l}100 \mathrm{ml} \\
50 \mathrm{ml} \\
25 \mathrm{ml} \\
25 \%\end{array}$ \\
\hline TEV elution Buffer & $\begin{array}{l}\text { Tris- } \mathrm{HCl}, \mathrm{pH} 8 \text { with } \mathrm{HCl} \\
\text { EDTA, pH } 8 \text { with } \mathrm{HCl} \\
\mathrm{NaCl} \\
\text { Glycerol } \\
\text { Triton-X100 } \\
\text { DTT }\end{array}$ & \begin{tabular}{|l|}
$50 \mathrm{mM}$ \\
$0.5 \mathrm{mM}$ \\
$100 \mathrm{mM}$ \\
$10 \%$ \\
$0.75 \%$ \\
$1 \mathrm{mM}$
\end{tabular} \\
\hline 2x SDS-PAGE loading Buffer & $\begin{array}{l}\text { Tris- } \mathrm{HCl} \mathrm{pH} 6.8 \text { with } \mathrm{HCl} \\
\text { SDS } \\
\text { Glycerol } \\
\text { Bromophenol blue } \\
\text { DTT }\end{array}$ & $\begin{array}{l}0.1 \mathrm{M} \\
4 \% \\
20 \% \\
0.20 \% \\
0.2 \mathrm{M}\end{array}$ \\
\hline
\end{tabular}

Table 1. Buffer recipes.

\section{Discussion}

We demonstrated that a single step TAP tag purification is a specific and efficient method for the purification of the Arabidopsis TOC-TIC complex. Although the TAP-tag would allow two successive purification steps (IgG- followed by calmodulin affinity purification after TEV protease-cleavage), we believe that in many cases the first affinity step followed by TEV protease cleavage will be sufficient. Our target, TOC159, is low abundant and the inclusion of the second calmodulin-affinity step excessively diminished the protein yield which was the main reason for excluding it from our present protocol. The TEV-elution in itself is a highly specific and gentle purification step that will only release the TAP-tagged target together with associated interaction partners while contaminating the proteins sticking non-specifically to the IgG resin will remain there. Thus, in combination with the IgG-affinity step, the TEV elution results in a sufficiently efficient purification for our and probably many others' purposes.

Care must be taken that the TAP-tagged construct is fully functional in vivo. TAP-tagging could have potentially deleterious effects on protein activity, stability or localization. TOC159 consists of three domains, the N-terminal acidic domain, the central GTP-binding domain and C-terminal membrane domain, that anchors TOC159 in the outer chloroplast membrane ${ }^{2}$. To avoid potential interference with membrane insertion, we fused the TAP-tag to the $\mathrm{N}$-terminus of TOC159. Fusion to the $\mathrm{N}$-terminus is rather the exception than the rule. Many proteins contain $\mathrm{N}$-terminal targeting information and should therefore by tagged at the C-terminus. We assured that TOC159 is functional in vivo by complementation of the ppi2 mutant (an albino mutant lacking TOC159) with TAP-TOC159. The rescue of the green, wild type phenotype indicated that TAP-TOC159 was functional ${ }^{15}$.

The purification protocol was used to identify new interaction partners of TOC159, that included KOC1 and TIC56 $6^{10,11}$. In total, around 30 proteins were associated with the complex suggesting that new interaction partners will be isolated and characterized in the near future. While we highly recommend the TAP-tag for complex purification, we would still like to point out that additional versions to the one presented here exist and may be very useful for some applications. 


\section{Disclosures}

The authors declare no competing interests.

\section{Acknowledgements}

The work was supported by grants from the Swiss National Science Foundation (31003A_156998 and 31003A_176191) and by the University of Neuchâtel.

\section{References}

1. Jarvis, P., \& López-Juez, E. Biogenesis and homeostasis of chloroplasts and other plastids. Nature Reviews Molecular Cell Biology. 14 (12), 787-802, (2013).

2. Kessler, F., \& Schnell, D. Chloroplast biogenesis: diversity and regulation of the protein import apparatus. Current opinion in cell biology. $\mathbf{2 1}$ (4), 494-500, (2009).

3. Schnell, D. J., Kessler, F., \& Blobel, G. Isolation of components of the chloroplast protein import machinery. Science. 266 (5187), 1007-1012, (1994).

4. Kessler, F., Blobel, G., Patel, H. A., \& Schnell, D. J. Identification of two GTP-binding proteins in the chloroplast protein import machinery. Science. 266 (5187), 1035-1039, (1994).

5. Jarvis, P. et al. An Arabidopsis mutant defective in the plastid general protein import apparatus. Science. 282 (5386), 100-103, (1998).

6. Bauer, J. et al. Essential role of the G-domain in targeting of the protein import receptor atToc159 to the chloroplast outer membrane. The Journal of cell biology. 159 (5), 845-854, (2002).

7. Kovacs-Bogdan, E., Soll, J., \& Bolter, B. Protein import into chloroplasts: the Tic complex and its regulation. Biochimica et biophysica acta. 1803 (6), 740-747, (2010).

8. Nakai, M. The TIC complex uncovered: The alternative view on the molecular mechanism of protein translocation across the inner envelope membrane of chloroplasts. Biochimica et biophysica acta. 1847 (9), 957-967, (2015).

9. Kikuchi, S. et al. Uncovering the protein translocon at the chloroplast inner envelope membrane. Science. 339 (6119), 571-574, (2013).

10. Kohler, D. et al. Characterization of chloroplast protein import without Tic56, a component of the 1-megadalton translocon at the inner envelope membrane of chloroplasts. Plant physiology. 167 (3), 972-990, (2015).

11. Zufferey, M. et al. The novel chloroplast outer membrane kinase KOC1 is a required component of the plastid protein import machinery. The Journal of biological chemistry. 292 (17), 6952-6964, (2017).

12. Rigaut, G. et al. A generic protein purification method for protein complex characterization and proteome exploration. Nature biotechnology. 17 (10), 1030-1032, (1999).

13. Rohila, J. S., Chen, M., Cerny, R., \& Fromm, M. E. Improved tandem affinity purification tag and methods for isolation of protein heterocomplexes from plants. The Plant journal. 38 (1), 172-181, (2004).

14. Rohila, J. S. et al. Protein-protein interactions of tandem affinity purified protein kinases from rice. PloS one. 4 (8), e6685, (2009).

15. Agne, B. et al. The acidic A-domain of Arabidopsis TOC159 occurs as a hyperphosphorylated protein. Plant physiology. 153 (3), 1016-1030, (2010).

16. Wessel, D., \& Flugge, U. I. A method for the quantitative recovery of protein in dilute solution in the presence of detergents and lipids. Analytical biochemistry. 138 (1), 141-143, (1984). 